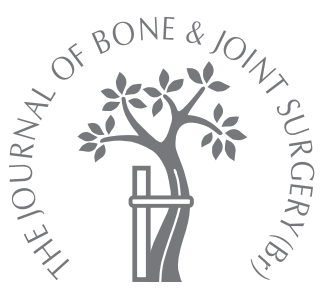

S. S. Jameson,

D. J. Langton,

A. V. F. Nargol

From The University

Hospital of North

Tees, Stockton-on-

Tees, England

\title{
Articular Surface Replacement of the hip: a prospective single-surgeon series
}

We present the early clinical and radiological results of Articular Surface Replacement (ASR) resurfacings in 214 hips (192 patients) with a mean follow-up of 43 months (30 to 57). The mean age of the patients was 56 years (28 to 74 ) and 85 hips $(40 \%)$ were in 78 women.

The mean Harris hip score improved from 52 (11 to 81) to 95 (27 to 100) at two years and the mean University of California, Los Angeles activity score from 3.9 (1 to 10) to 7.4 (2 to 10) in the same period. Narrowing of the neck (to a maximum of $9 \%$ ) was noted in 124 of 209 hips (60\%). There were 12 revisions $(5.6 \%)$ involving four $(1.9 \%)$ early fractures of the femoral neck and two $(0.9 \%)$ episodes of collapse of the femoral head secondary to avascular necrosis. Six patients $(2.8 \%)$ had failure related to metal wear debris. The overall survival for our series was $93 \%$ (95\% confidence interval 80 to 98 ) and $89 \%$ (95\% confidence interval 82 to 96) for hips with acetabular components smaller than $56 \mathbf{~ m m}$ in diameter.

The ASR implant has a lower diametrical clearance and a subhemispherical acetabular component when compared with other more frequently implanted metal-on-metal hip resurfacings. These changes may contribute to the higher failure rate than in other series, compared with other designs. Given our poor results with the small components we are no longer implanting the smaller size.

Resurfacing arthroplasty of the hip using metal-on-metal bearings is commonly offered to younger, active patients who require surgical intervention. In these patients the survival rates of implants after total hip replacement (THR) are relatively poor. $^{1,2}$ In 2007 , 9\% of all primary hip arthroplasty procedures performed in England and Wales were resurfacings ${ }^{3}$ and the advantages of this procedure have been well documented. ${ }^{4-9}$ The short-term outcome is comparable with that of THR in age- and gender-matched groups, ${ }^{10}$ and the patients have higher levels of activity and a better quality of life. ${ }^{11,12}$

Hip resurfacing has provided excellent success rates in young patients with osteoarthritis (OA) in specialist centres. ${ }^{13-15}$ The medium-term results from independent units have corroborated these findings. ${ }^{16-18}$ Fracture of the neck of the femur is thought to be the most common complication, with reported rates ranging from $0 \%$ to $6 \%{ }^{10,13-15,19,20}$ Other modes of failure include osteonecrosis of the residual head and, of particular concern, reactions to metal wear debris resulting in persisting pain, 'pseudotumours' and softtissue destruction. ${ }^{6,21-23}$
A number of specific modifications in design have been made to the latest generation of implants in an attempt to improve implantation, function and survival. ${ }^{24,25}$ The Articular Surface Replacement (ASR) (DePuy International Ltd, Leeds, United Kingdom) has a low diametrical clearance (mean $100 \mu \mathrm{m}$ ) to reduce metal wear, a subhemispherical design of the acetabular component to preserve acetabular bone stock and an internal geometrical taper of the femoral head of $3^{\circ}$ to improve seating. ${ }^{26}$ The femoral stem is thinner and over-reamed to reduce the risk of stress-shielding ${ }^{20}$ and narrowing of the neck, which has been described in other designs. ${ }^{27,28}$ Currently, this prosthesis is the second most commonly implanted resurfacing design in England and Wales. ${ }^{3}$

Data from the designers' series of 300 ASRs have only been reported for a mean follow-up of 202 days $^{20}$ and no mid-term findings have been published. Emerging data from national joint registers have shown early revision rates for resurfacing implants to be higher than anticipated but the reasons for this remain unknown. ${ }^{3,29}$ This study describes our experience of using this design of prosthesis. 


\section{Patients and Methods}

Between April 2004 and September 2006, 214 consecutive hips in 192 patients were resurfaced using the ASR by the senior author (AVFN). Details of the patients, their diagnoses, the American Society of Anaesthesiology (ASA) grade ${ }^{30}$ and the Charnley walking grade ${ }^{31}$ were recorded (Table I). A consultant radiologist assessed the Ficat stage of patients with avascular necrosis (AVN). ${ }^{32}$ The mean age at the time of surgery was 56 years (28 to 74$)$. There were 114 males (129 hips) and 78 females ( 85 hips), with 22 patients receiving bilateral resurfacing. Of these, 12 had staged operations at a mean of eight months between procedures (3 to 13).

There were no specific selection criteria, but physiologically young and active patients with hip disease requiring surgical intervention were considered for resurfacing. Women over 65 years and men over 75 years of age were not routinely offered the procedure. There was an expectation that patients offered resurfacing would return to a reasonably active lifestyle, including sports in many cases. Resurfacing was not considered in patients with renal dysfunction. Radiological evidence of considerable cystic change in the femoral head was not a contraindication to resurfacing. The final decision on whether to procede to resurfacing or THR was based on the intraoperative findings. The quality of bone was assessed on plain radiographs by the senior author and the patients were not routinely scanned for osteoporosis. None reported previous sensitivity reactions to metal.

The results of contemporary metal-on-metal articulations were discussed with the patients before operation and as information regarding complications from metal debris became available, this was mentioned. The risk of fracture of the femoral neck was quoted as $1 \%$ and the options for revision were explained. All the patients agreed to prospective clinical and radiological follow-up.

Operative technique. All the procedures were performed through a posterior approach with detachment of the short external rotators. The acetabulum was prepared by underreaming by $1 \mathrm{~mm}$ according to the manufacturer's recommendations. The acetabular component was then inserted firmly by press-fit in $45^{\circ}$ of inclination and $15^{\circ}$ to $25^{\circ}$ of anteversion. The femoral head was sized according to the diameter of the neck and reamed with care to avoid notching of the neck. The stem of the femoral component was placed between $0^{\circ}$ and $10^{\circ}$ of valgus to reduce the risk of fracture of the neck. ${ }^{33}$ Any cysts in the head were filled with graft using reamed bone when necessary. Low-viscosity vacuum-mixed cement was used to secure the femoral component to the reamed femoral head. This was then reduced and the external rotators reattached. The wound was closed in layers without a drain.

The patients were given second-generation cephalosporin pre-operatively and for a further two doses postoperatively. In order to reduce the risk of thromboembolism, all the patients wore calf pumps during their stay in hospital and compression stockings for six weeks from the day of surgery. High-risk patients were given subcutaneous low-molecular-weight heparin for one week, as defined by hospital guidelines. Post-operatively, the patients were allowed to bear full weight immediately unless there were large cysts in the femoral head which had been grafted or if the neck had been notched, when the use of crutches and touch weight-bearing was advised for six weeks. All were told to avoid high-impact sports such as jogging, tennis and squash for six months, after which such restrictions were lifted. The design of the prosthesis and the surgical technique did not change throughout the period of study. Clinical outcome. Pre-operative clinical assessment was performed using the Harris hip score (HHS) ${ }^{34}$ and the University of California, Los Angeles (UCLA) activity score. $^{35}$ These scores were repeated post-operatively at annual intervals. After two years, the patients were also asked to rate their satisfaction with the procedure on a five-point scale $(0$, not satisfied, 1 minimally satisfied, 2 moderately satisfied, 3 , satisfied to 4, extremely satisfied), and to indicate if they could undertake all the activities which they had hoped to be capable of after surgery. Radiological assessment. Digital standing anteroposterior (AP) pelvic radiographs were taken pre-operatively and before discharge after surgery, after three and 12 months and annually thereafter. Care was taken to ensure that the patients were correctly positioned in order to minimise pelvic rotation. AGFA IMPAX ES Web 1000 version 5.1 (Agfa-Gevaert Group, Mortsel, Belgium) and Einzel-BildRoentgen-Analyse (EBRA, University of Innsbruck, Innsbruck, Austria) software were used for analysis throughout the study. All the angles reported were measurements from radiographs and may have differed from the articular and intraoperative angles. ${ }^{36}$ All radiological measurements were performed by two of the authors (SSJ, DJL) and the mean values taken. The neck-shaft angle, the stem-shaft angle and the stem-neck angle were measured using the AGFA software (Fig. 1a). The position of the acetabular component as to anteversion and inclination was measured using the EBRA software, which has previously been described and validated for this group of patients (Fig. 1b). ${ }^{37}$ We noted radiolucent lines measuring over $1 \mathrm{~mm}$ around the acetabular component in the zones of DeLee and Charnley, ${ }^{38}$ as modified by Beaule et $a l,{ }^{39}$ and around the femoral stem in the zones of Amstutz et $\mathrm{al}^{40}$ (Fig. 2). Thinning of the neck was calculated using component head:neck ratios to avoid errors due to magnification (Fig. 3). ${ }^{40}$ The percentage of thinning at follow-up could then be accurately calculated from the immediate post-operative diameter of the neck. Thinning of the neck and radiolucency around the components were assessed on radiographs taken two years after the procedure (209 hips). Radiographs were also assessed for heterotopic ossification (HO) according to the classification of Brooker et $\mathrm{al}^{41}$ (Table II).

Hips which had been revised were excluded from postoperative functional analysis if the revision occurred before 
Table I. Details of the patients, radiological measurements and outcome data

\begin{tabular}{|c|c|c|}
\hline Number of hips (patients) & 214 & (192) \\
\hline Mean (range) age in years & 56 & (28 to 74 ) \\
\hline Number of women (\%) & 85 & $(40)$ \\
\hline Mean (range) post-operative time in months & 43 & (30 to 57 ) \\
\hline Mean (range) body mass index in $\mathrm{kg} / \mathrm{m}^{2}$ & 27 & (19 to 30$)$ \\
\hline Mean (range) $\mathrm{ASA}^{*}$ grade & & $4(1$ to 2$)$ \\
\hline Number (\%) of Charnley grade A & 107 & $(50)$ \\
\hline \multicolumn{3}{|l|}{ Indication (number, \%) } \\
\hline Primary osteoarthritis & 145 & (68) \\
\hline Avascular necrosis & 591 & (28) \\
\hline \multicolumn{3}{|l|}{ Ficat grade } \\
\hline II & 81 & (4) \\
\hline III & 34 & (16) \\
\hline IV & 171 & (8) \\
\hline Developmental dysplasia & 101 & (5) \\
\hline \multicolumn{3}{|l|}{ Procedure } \\
\hline Unilateral (number, \%) & 170 & (79) \\
\hline Median (range) femoral head size in $\mathrm{mm}$ & 491 & (41 to 59 ) \\
\hline Median (range) acetabular component size in $\mathrm{mm}$ & 56 & (46 to 66$)$ \\
\hline Bone grafting to cysts (number, \%) & 161 & (7) \\
\hline \multicolumn{3}{|l|}{ Radiological measurements } \\
\hline Mean (range) neck-shaft angle $\left({ }^{\circ}\right)$ & 132 & (118 to 152$)$ \\
\hline Mean (range) acetabular component inclination angle $\left(^{\circ}\right)$ & 49 & (31 to 67$)$ \\
\hline Mean (range) acetabular component anteversion angle $\left({ }^{\circ}\right)$ & 20 & (3 to 29$)$ \\
\hline Mean (range) stem-neck angle $\left({ }^{\circ}\right)$ & 9 & $(-11 \text { to }-28)^{\dagger}$ \\
\hline Mean (range) stem-shaft angle $\left({ }^{\circ}\right)$ & 140 & (111 to 157$)$ \\
\hline Acetabular component lucency lines (number, \%) & 411 & (19) \\
\hline I & 30 & (14) \\
\hline II & 81 & (4) \\
\hline III & 41 & (2) \\
\hline IV & 11 & (0) \\
\hline Two or more zones (number, \%) & 21 & (1.0) \\
\hline Cup migration (number) & 01 & $(0.0)$ \\
\hline Stem lucency lines (number, \%) & 101 & (5) \\
\hline 1 & 81 & (4) \\
\hline II & 0 & (0) \\
\hline III & 21 & (1) \\
\hline Two or more zones & 01 & (0) \\
\hline Stem migration (number) & 01 & (0) \\
\hline Neck thinning (number, \%) & 124 & (60) \\
\hline Mean (range) \% thinning (number) & 61 & (1 to 9$)$ \\
\hline Heterotopic ossification (number, \%) & 94 & (44) \\
\hline \multicolumn{3}{|l|}{ Brooker grade (number, \%) } \\
\hline 1 & 761 & (36) \\
\hline 2 & 181 & (8) \\
\hline 3 and 4 & 0 & (0) \\
\hline \multicolumn{3}{|l|}{ Pre-operative scores (214 hips) } \\
\hline Mean (range) $\mathrm{HHS}^{\ddagger}$ & 52 & (11 to 81 ) \\
\hline Mean (range) UCLA ${ }^{\S}$ activity score & & $9(1$ to 10$)$ \\
\hline Mean (range) flexion $\left({ }^{\circ}\right)$ & 71 & (30 to 110$)$ \\
\hline \multicolumn{3}{|l|}{ Outcome scores at one year (210 hips) } \\
\hline Mean (range) HHS & 95 & (45 to 100$)$ \\
\hline Mean (range) UCLA activity score ${ }^{\dagger}$ & 6.8 & $(2.0$ to 10.0$)$ \\
\hline Mean (range) flexion $\left({ }^{\circ}\right)$ & 100 & (45 to 140$)$ \\
\hline \multicolumn{3}{|l|}{ At one year (209 hips) } \\
\hline Mean (range) HHS & 95 & (27 to 100$)$ \\
\hline Mean (range) UCLA activity score ${ }^{\dagger}$ & 7.4 & $(2.0$ to 10.0$)$ \\
\hline Mean (range) flexion $\left({ }^{\circ}\right)$ & 103 & (45 to 140$)$ \\
\hline Highly satisfied (number, \%) & 192 & (92) \\
\hline All activities they wish (number, \%) & 161 & (77) \\
\hline \multicolumn{3}{|l|}{ * ASA, American society of anaesthesiologists } \\
\hline \multicolumn{3}{|c|}{$\begin{array}{l}\dagger \text { positive value represents valgus position. Radiological loosening and neck thinning based on lat- } \\
\text { est radiographs }\end{array}$} \\
\hline \multicolumn{3}{|l|}{ ‡ HHS, Harris hip score } \\
\hline$\S$ UCLA, University of California, Los Angeles & & \\
\hline
\end{tabular}




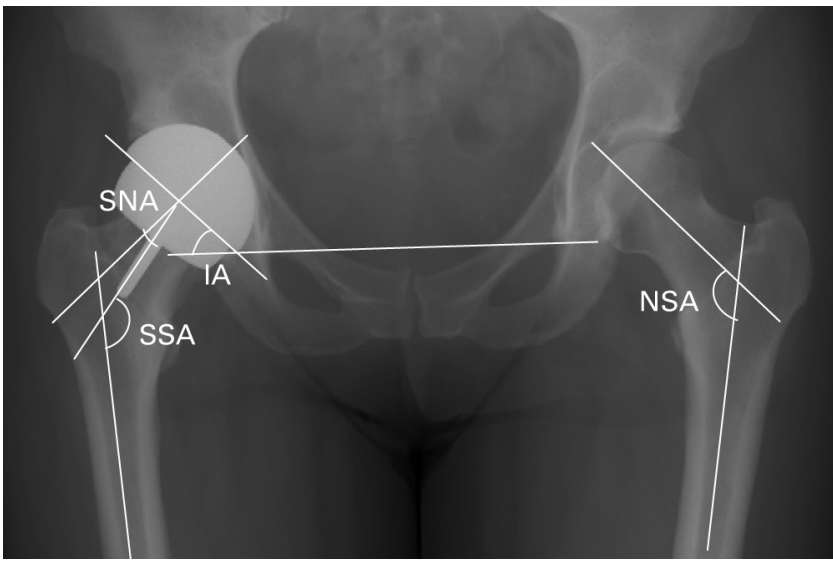

Fig. 1a

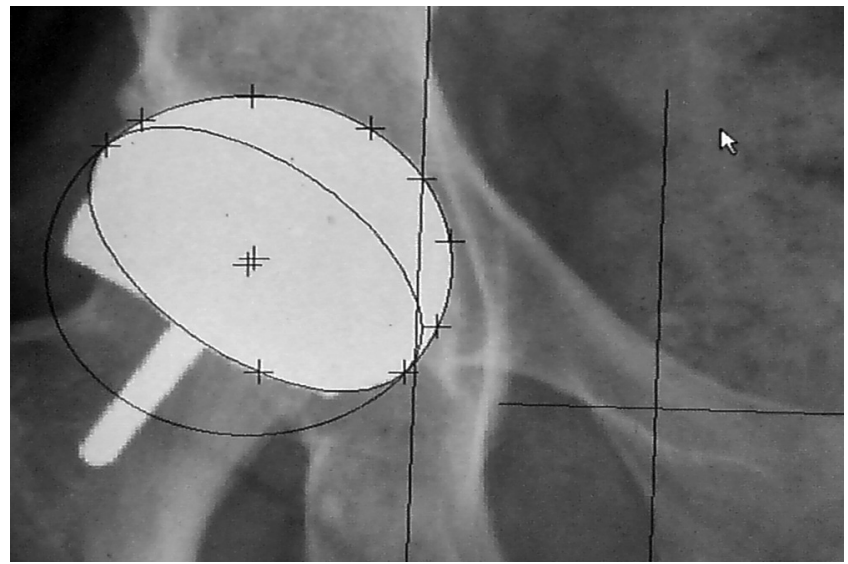

Fig. $1 \mathrm{~b}$

Radiograph showing a) measurement of the neck-shaft angle on the contralateral hip for illustrative purposes only, the stem-neck angle (SNA) and the inclination angle (IA) (SSA, stem-shaft angle, NSA, neck-shaft angle) and b) calculation of the anteversion angle using EBRA software.

the assessment at one or two years. The intraoperative findings and complications were recorded. Failure was defined as a revision procedure for any reason.

Statistical analysis. Analysis of the Kaplan-Meier survival curves was carried out using SPSS version 16 (SPSS Inc., Chicago, Illinois).

\section{Results}

No patients were lost to follow-up. There were no deaths, but 12 hips were revised $(5.6 \%)$. There were four acute fractures $(1.9 \%)$, and in two hips $(0.9 \%)$ the femoral head had collapsed $(0.9 \%)$ secondary to AVN. One patient had a late fracture after two years associated with gross metallosis. Five $(2.6 \%)$ had a post-operative HHS below 50 at two years and, because of persistent pain restricting activity, have subsequently been revised. Five hips were revised before the assessment at two years. The clinical results were therefore based on the remaining 209 hips in 187 patients. The mean HHS improved from 52 (11 to 81 ) pre-operatively to 95 (45 to 100). An excellent HHS, defined as 90 or above, occurred in $182(87 \%)$. The mean UCLA activity score improved from 3.9 (1.0 to 10.0$)$ pre-operatively to 7.4 (2.0 to 10.0$)$ at two years and the mean hip flexion, as part of the HHS analysis, from $71^{\circ}\left(30^{\circ}\right.$ to $\left.110^{\circ}\right)$ to $103^{\circ}$ $\left(45^{\circ}\right.$ to $\left.140^{\circ}\right)$ during the same interval. A high satisfaction score (3 or 4) for the outcome was reported in 192 (92\%) and $161(77 \%)$ were able to perform all the activities which they had anticipated doing after the surgery. The results are summarised in Tables I and III.

Radiological analysis. The acetabular component was placed at a mean inclination of $49^{\circ}\left(31^{\circ}\right.$ to $\left.67^{\circ}\right)$ with a mean of $20^{\circ}$ $\left(3^{\circ}\right.$ to $\left.29^{\circ}\right)$ of anteversion. At two years, 124 hips $(59.3 \%)$ had evidence of thinning of the neck, all within $10 \%$ of the original width. Two hips had lucent lines in two or more zones around the acetabular component. One of these patients subsequently required revision for pain. In addition, a hip revised for fracture of the femoral neck before the two- year review had acetabular lucencies in all four zones, but these had been present since implantation and the acetabular component was not found to be loose at revision. There were no other hips with lucent lines in two or more zones around the femoral stem. Heterotopic ossification ( $\mathrm{HO})$ was seen around 94 hips (44\%), all of which were Brooker grade I and II.

Complications. Superficial wound infection occurred in eight hips and was successfully managed with antibiotics. A further patient on long-term treatment with warfarin for a mechanical cardiac valve, developed a deep wound infection which was treated by surgical debridement and antibiotic therapy for six weeks. The implant was retained and at two years after the procedure his HHS was 90. There was one case of deep-vein thrombosis which was treated with warfarin for six weeks. No implant was removed because of infection and there were no dislocations.

Revisions. In four patients (two men, two women) early fracture of the femoral neck was observed at a mean of 10 months (2 to 24 ) after operation. In each case, there was a sudden onset of pain, with no history of trauma. Two occurred within three months of operation and these patients were excluded from the one-year clinical followup. Of the 12 hips noted to have sustained a notch in the femoral neck, three went on to fracture, two within three months. A further two patients had increasing discomfort from their resurfaced hip in which the initial radiographs had been unremarkable. They subsequently developed collapse of the femoral head as a result of AVN, confirmed on histological analysis, and were revised.

The six patients with early failure of the femoral head or neck had a femoral revision to an uncemented THR comprising a modular ASR XL (DePuy International Ltd) head and an S-ROM (DePuy International Ltd) femoral stem. The acetabular component was left in situ. There was no evidence of excess metal wear or metallosis and, at a mean of 24 months (13 to 31 ) after revision, the mean HHS was 82 


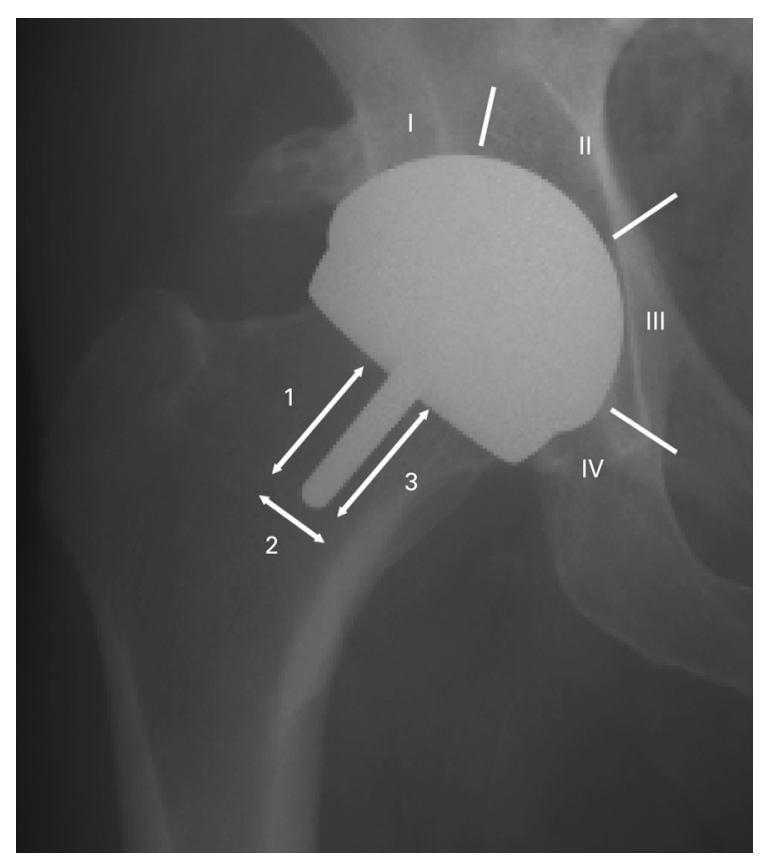

Fig. 2

Radiograph showing the radiolucent zones of DeLee and Charnley $^{38}$ (acetabular side, modified by Beaulé et $\mathrm{al}^{39}{ }^{39}$ to IV) and of Amstutz et al ${ }^{40}$ (femoral stem, 1 to 3).

(48 to 99) and the mean UCLA activity score was 6 (4 to 8 ) in five of these patients. Despite their complications four patients stated that they were extremely satisfied with their outcome. One of the six patients had ongoing pain after revision and eventually underwent a second revision to a ceramic-bearing THR.

One man had a late fracture of the femoral neck at 35 months. The hip became painful suddenly and rapidly worsened. There was no history of trauma. The CT confirmed the fracture. At revision there was gross black staining and necrosis of the soft tissue.

A further five women had a revision because of persistent severe pain. At the two-year follow-up their HHSs were poor (50, 42, 35, 30 and 27, respectively). The symptoms and clinical findings were similar in all five, although the time of onset of pain varied. Three had an early and progressive deterioration in symptoms. The others were initially extremely satisfied and then gradually began to have pain in the groin at between two and 28 months after the procedure. Haematological screening for infection was normal and each patient underwent aspiration of the hip under fluoroscopic guidance. The aspirations yielded differing volumes of milky green/grey fluid. At revision in all five patients there was gross swelling of the pseudocapsule caused by an accumulation of the fluid, which was bathing the implant and tracking into the psoas tendon. One acetabular component was found to be loose with radiolucent lines in three zones.

Histopathological analysis of tissue samples from the five women with unexplained pain and the man with the

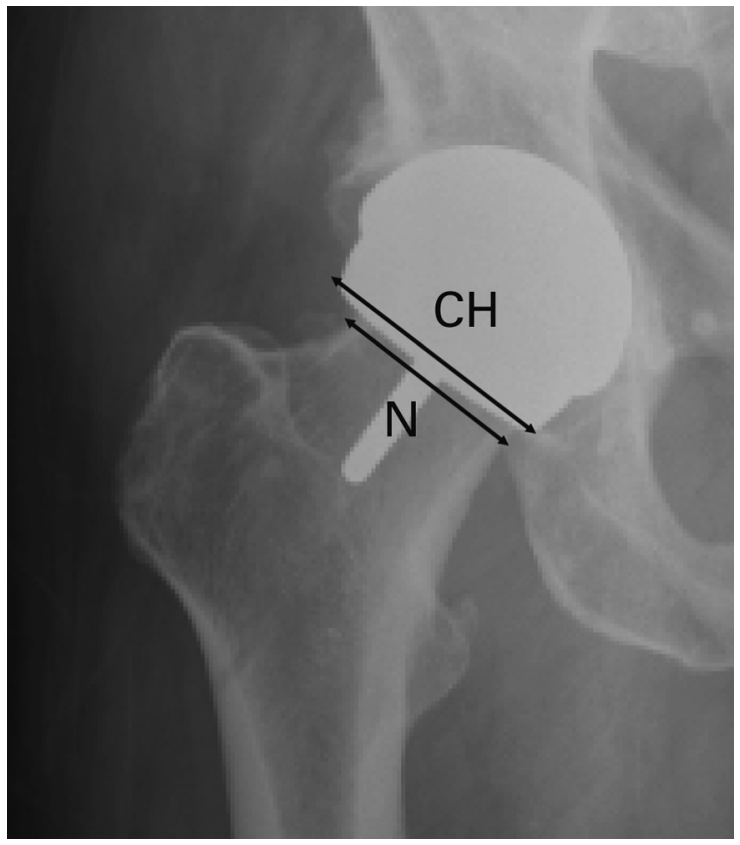

Fig. 3

Radiograph showing the measurements taken from a standardised AP radiograph of the pelvis to calculate the component head $(\mathrm{CH})$ : neck $(\mathrm{N})$ ratio.

late fracture showed tissue necrosis in all patients. All viable tissue samples had areas with high numbers of lymphocytes forming cuffs around vascular tissue. Synovial ulceration was also frequently seen. The tissue and fluid samples failed to culture organisms in any of the patients.

All the patients with evidence of metal wear debris, including the late fracture, had revision to ceramic-bearing THRs with a rapid and sustained improvement in symptoms (Table IV). The revisions with evidence of metal wear debris have been analysed in detail in a further study. ${ }^{42}$

Survivorship. Kaplan-Meier survival analysis showed a survival rate of $93 \%$ (95\% confidence interval (CI) 80 to 98) at a mean of 43 months with 202 hips remaining at risk (Fig. 4a). Small acetabular components had been used in nine of the 12 failures. Further survival analysis on 'large' ( $\geq 56 \mathrm{~mm}$ ) and 'small' (<56 mm) acetabular components showed that large components had a greater survival rate (97\% (95\% CI 80 to 98 ) compared with $89 \%$ (95\% CI 82 to 96$)$; Fig. 4b). There were no failures in men $<55$ years of age.

\section{Discussion}

The functional outcome in patients treated using the ASR system mirrors the satisfactory outcomes following other types $^{13-15}$ of resurfacing. The patients reported extremely high subjective satisfaction scores. However, the revision rate of $5.6 \%$ in our series is a concern. The early fracture rate of $1.9 \%$ was comparable to reports in the

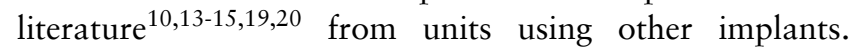


Table II. Classification of heterotopic ossification according to Brooker et al ${ }^{41}$

\begin{tabular}{ll}
\hline Grade & Description \\
\hline 1 & Islands of bone within soft tissue about the hip \\
2 & $\begin{array}{l}\text { Bone spurs from the pelvis or the proximal end of the femur, leaving at least } 1 \mathrm{~cm} \text { between opposing bone } \\
\text { surfaces }\end{array}$ \\
3 & $\begin{array}{l}\text { Bone spurs from the pelvis or the proximal end of the femur, reducing the space between opposing bone } \\
\text { surfaces to }<1 \mathrm{~cm}\end{array}$ \\
4 & Apparent hip ankylosis \\
\hline Reprinted with permission from The Journal of Bone and Joint Surgery [Am]
\end{tabular}

Table III. Details of complications

\begin{tabular}{llr}
\hline & Complication & Number (\%) \\
\hline Peri-operative & Neck notch & $12(5.6)$ \\
& Superior & $7(3.3)$ \\
& Inferior & $5(2.3)$ \\
& Retention of femoral guide pin & $1(0.5)$ \\
& Fracture & $0(0.0)$ \\
& & \\
Post-operative & Superficial wound & $8(3.7)$ \\
& Ongoing severe pain (HHS < 50) & $5(2.3)$ \\
& Early neck fracture & $4(1.9)$ \\
& Late neck fracture and metallosis & $1(0.5)$ \\
& Deep infection with debridement & $1(0.5)$ \\
DVT & $1(0.5)$ \\
Revisions & PE & $0(0.0)$ \\
& All & $12(5.6)$ \\
& Acute neck fractures & $4(1.9)$ \\
& Osteonecrosis of head & $2(0.9)$ \\
& Infection & $0(0.0)$ \\
& Probable metal debris-related & $6(2.8)$ \\
\hline HHS, Harris hip score; DVT, deep-vein thrombosis; PE, pulmonary embolism
\end{tabular}

Shimmin and Back ${ }^{19}$ showed that notching of the femoral neck was a risk factor for the development of a fracture of the neck. In our series three of the 12 patients who had a notch in the femoral neck at the time of surgery subsequently sustained a fracture.

In their review of fractures following Birmingham Hip Resurfacing (BHR, Smith and Nephew, Warwick, United Kingdom), Shimmin and Back ${ }^{19}$ found that all fractures occurred within one year but in our patients two of four fractures occurred later than this. All four patients had a neck-shaft angle of less than $130^{\circ}$. As part of the radiological selection criteria for hip resurfacing, it is desirable to have a higher neck-shaft angle of the femur in order to reduce the possible risk of fracture of the femoral neck.

Siebel et $\mathrm{al}^{20}$ followed up a series of 300 ASRs for a mean of only 202 days and the outcome scores were measured at three months. After primary THR, the outcome scores do not plateau until 12 to 18 months after surgery. ${ }^{43}$ Siebel et $\mathrm{al}^{20}$ had a revision rate of $2.7 \%$ at this early stage, with five fractures of the neck $(1.7 \%)$ and three revisions $(1 \%)$ of the acetabular component. All the fractures occurred within four months of the procedure and $95 \%$ of their patients were satisfied. Despite our failure rate at a mean of
43 months being approximately twice that quoted by Siebel et $a{ }^{20}$ the rates of fracture of the femoral neck are similar, at $1.9 \%$. However, Siebel et $\mathrm{al}^{20}$ described only one revision for pain and the macroscopic changes in tissue were not discussed.

Despite the potential benefits of metal-on-metal bearing surfaces, such as reduced volumetric wear, a lower risk of osteolysis and less aseptic loosening compared with metal articulating against polyethylene ${ }^{44}$ there remain concerns. ${ }^{45}$ Local and systemic effects of high amounts of debris from metal wear are yet to be fully understood. ${ }^{45-48}$ In our series five patients had persistent severe pain with poor outcome scores related to metallosis. A further patient had a late fracture associated with gross metal wear. At revision all patients showed similar macro- and microscopic tissue changes. In the 1970s there was a high incidence of unexplained metal-on-metal THR failure in patients who were sensitive to metallic patch testing. ${ }^{49}$ Sweetnam ${ }^{50}$ described an immune reaction in the deep tissues around buried cobalt and chromium metals which was thought to lead to obliterative vascular changes, local bone necrosis and loosening of the metal prosthesis. More recently, Willert et al ${ }^{21}$ described an aseptic lymphocyte-dominated vasculitis-associated lesion 
Table IV. Details of patients revised

\begin{tabular}{|c|c|c|c|c|c|c|c|c|c|c|c|c|c|c|c|}
\hline \multirow[b]{2}{*}{$\begin{array}{l}\text { Age } \\
\text { (yrs) }\end{array}$} & \multirow[b]{2}{*}{ Gender } & \multirow[b]{2}{*}{$\begin{array}{l}\text { Months } \\
\text { in situ }\end{array}$} & \multirow[b]{2}{*}{ ASA } & \multirow[b]{2}{*}{${ }^{*}{ }_{\left(\mathrm{kg} / \mathrm{m}^{2}\right)}^{\mathrm{BMI}}$} & \multirow[b]{2}{*}{$\begin{array}{l}\text { Indica- } \\
\text { tion for } \\
\text { primary } \\
\text { surgery }^{\ddagger}\end{array}$} & \multirow[b]{2}{*}{$\begin{array}{l}\text { Intra-operative } \\
\text { comments }\end{array}$} & \multirow{2}{*}{$\begin{array}{l}\text { Acetabular } \\
\text { component posi- } \\
\text { tion (anteversion } \% \\
\text { inclination }{ }^{\circ} \text { ) }\end{array}$} & \multirow{2}{*}{$\begin{array}{l}\text { Head/ } \\
\text { acetabular } \\
\text { component } \\
\text { size }(\mathrm{mm})\end{array}$} & \multicolumn{3}{|c|}{$\begin{array}{l}\text { Femoral } \\
\text { position }\left({ }^{\circ}\right)^{\S}\end{array}$} & \multicolumn{2}{|c|}{$\begin{array}{l}\text { Latest } \\
\text { scores }\end{array}$} & \multirow[b]{2}{*}{$\begin{array}{l}\text { Mechanism } \\
\text { of failure }\end{array}$} & \multirow[b]{2}{*}{ Comments } \\
\hline & & & & & & & & & NSA & SNA & A SSA & HHS & UCLA & & \\
\hline $63^{*}$ & $\mathrm{M}$ & 12 & 2 & 29 & $\mathrm{OA}^{\ddagger}$ & Superior notch & 19/43 & $49 / 56$ & 128 & 8 & 136 & 90 & 7 & $\begin{array}{l}\text { Acute } \\
\text { femoral neck } \\
\text { fracture }\end{array}$ & \\
\hline $62^{*}$ & $\mathrm{M}$ & 2 & 2 & 28 & OA & Superior notch & 14/52 & $51 / 58$ & 125 & 1 & 126 & - & - & $\begin{array}{l}\text { Acute } \\
\text { femoral neck } \\
\text { fracture }\end{array}$ & \\
\hline 57 & $\mathrm{~F}$ & 3 & 2 & 27 & OA & $\begin{array}{l}\text { Inferior } \\
\text { notch }\end{array}$ & $21 / 42$ & $43 / 48$ & 128 & 3 & 131 & - & - & $\begin{array}{l}\text { Acute } \\
\text { femoral neck } \\
\text { fracture }\end{array}$ & \\
\hline 58 & $\mathrm{~F}$ & 24 & 2 & 30 & OA & - & $22 / 55$ & $47 / 54$ & 124 & 16 & 140 & 100 & 7 & $\begin{array}{l}\text { Acute } \\
\text { femoral } \\
\text { neck fracture }\end{array}$ & \\
\hline 49 & $\mathrm{~F}$ & 17 & 1 & 26 & $\begin{array}{l}\text { AVN } \\
\text { (Ficat 2) }\end{array}$ & $\begin{array}{l}\text { Cysts - bone } \\
\text { grafted }\end{array}$ & $18 / 46$ & $45 / 50$ & 140 & 6 & 146 & 78 & 5 & AVN & \\
\hline 59 & $\mathrm{~F}$ & 37 & 2 & 27 & OA & - & $20 / 45$ & $47 / 54$ & 136 & 10 & 146 & 100 & 9 & AVN & \\
\hline 59 & $\mathrm{M}$ & 35 & 1 & 31 & OA & - & $19 / 49$ & $47 / 54$ & 133 & 8 & 141 & 100 & 7 & $\begin{array}{l}\text { Failure related } \\
\text { to metal wear } \\
\text { debris }\end{array}$ & $\begin{array}{l}\text { Initially } \\
\text { excellent. } \\
\text { femoral neck } \\
\text { fracture/metal } \\
\text { wear debris at } \\
\text { revision }\end{array}$ \\
\hline 60 & $\mathrm{~F}$ & 28 & 2 & 32 & OA & - & $29 / 57$ & $43 / 48$ & 133 & 4 & 137 & 50 & 3 & $\begin{array}{l}\text { Failure related } \\
\text { to metal wear } \\
\text { debris }\end{array}$ & $\begin{array}{l}\text { Local } \\
\text { anaesthetic } \\
\text { injection to } \\
\text { psoas tendon - } \\
\text { temporary } \\
\text { relief only }\end{array}$ \\
\hline 45 & $\mathrm{~F}$ & 47 & 2 & 34 & $\begin{array}{l}\text { AVN } \\
\text { (Ficat 3) }\end{array}$ & Difficult & $27 / 57$ & $46 / 52$ & 136 & 14 & 150 & 42 & 6 & $\begin{array}{l}\text { Failure related } \\
\text { to metal wear } \\
\text { debris }\end{array}$ & $\begin{array}{l}\text { Initially good } \\
\text { progress with } \\
\text { HHS } 99 \text { at two } \\
\text { years. Lucent } \\
\text { lines in three } \\
\text { zones around } \\
\text { acetabular } \\
\text { component. } \\
\text { Increasing } \\
\text { groin pain at } \\
\text { three years. } \\
\text { Acetabular } \\
\text { component } \\
\text { loose at } \\
\text { revision }\end{array}$ \\
\hline 58 & $\mathrm{~F}$ & 30 & 2 & 30 & OA & - & $27 / 53$ & $43 / 48$ & 134 & 12 & 146 & 27 & 3 & $\begin{array}{l}\text { Failure related } \\
\text { to metal wear } \\
\text { debris }\end{array}$ & $\begin{array}{l}\text { At one year } \\
\text { HHS } 94 . \\
\text { Worsening } \\
\text { groin pain, } \\
\text { relieved for } \\
\text { short period } \\
\text { with local } \\
\text { anaesthetic }\end{array}$ \\
\hline $36^{* *}$ & $\mathrm{~F}$ & 27 & 1 & 26 & $\begin{array}{l}\text { AVN } \\
\text { (Ficat 3) }\end{array}$ & $\begin{array}{l}\text { Defects- } \\
\text { bone grafted }\end{array}$ & $30 / 50$ & $51 / 58$ & 130 & 12 & 142 & 30 & 2 & $\begin{array}{l}\text { Failure related } \\
\text { to metal wear } \\
\text { debris }\end{array}$ & \\
\hline 47 & $\mathrm{~F}$ & 36 & 1 & 29 & OA & - & $27 / 61$ & $41 / 46$ & 133 & 12 & 145 & 35 & 4 & $\begin{array}{l}\text { Failure related } \\
\text { to metal wear } \\
\text { debris }\end{array}$ & \\
\hline
\end{tabular}

* ASA, American society of anaesthesiologists

$\dagger \mathrm{BMI}$, body mass index

‡ OA,osteoarthritis; AVN, avascular necrosis

§ NSA, neck-shaft angle; SNA, stem-neck angle; SSA, stem-shaft angle

I HHS, Harris hip score; UCLA, University of California, Los Angeles

** large acetabular components ( $\geq 56 \mathrm{~mm}$ )

in the tissue around metal-on-metal bearings. Analysis of tissue removed during revision of metal-on-metal had previously shown that most tissue had perivascular infiltration of lymphocytes, an accumulation of plasma cells and macrophages and tissue ulceration, which was not previously described in metal-on-polyethylene revisions. ${ }^{51}$ The histo- 


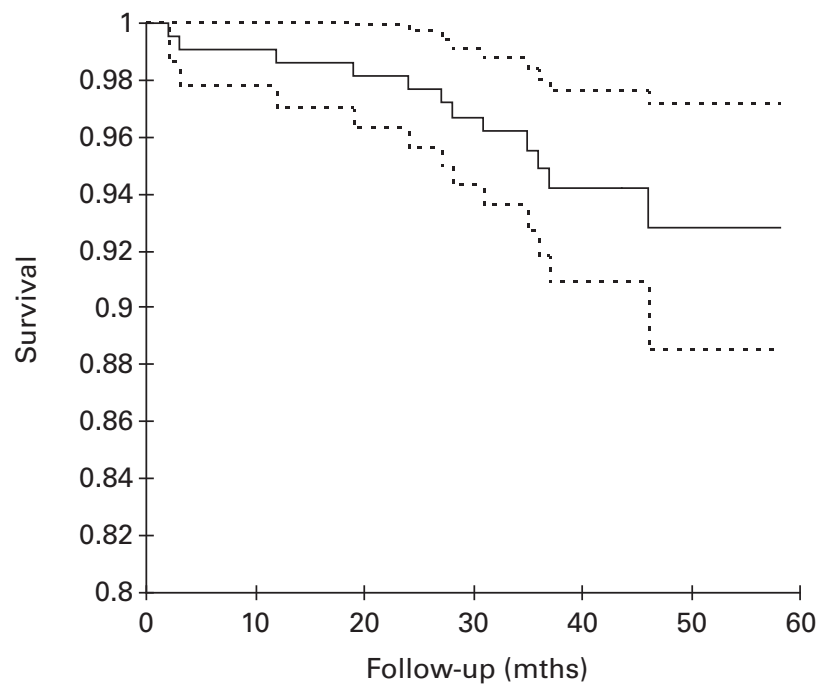

Fig. 4a

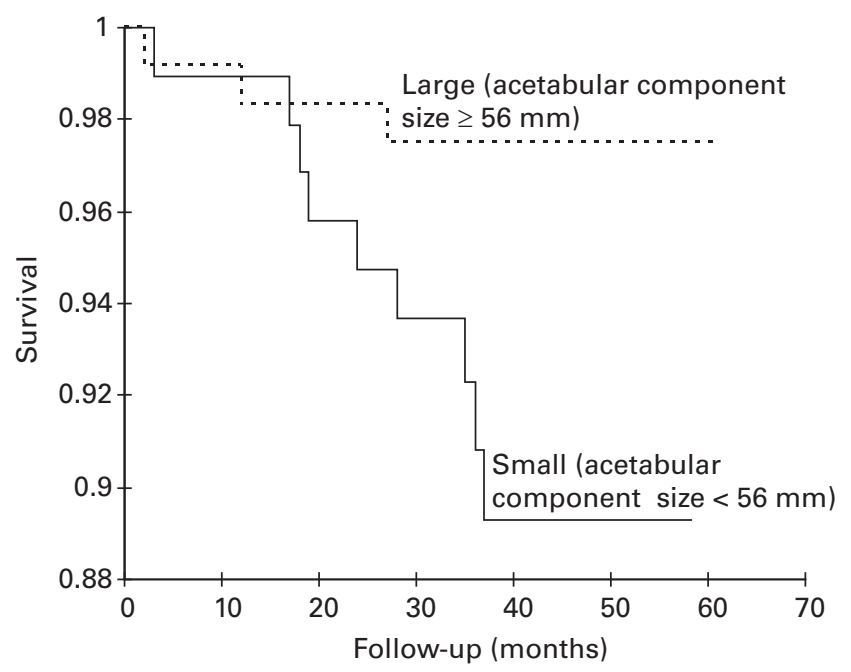

Fig. $4 b$

Kaplan-Meier survival curves for a) the entire series and b) separated by component size (large and small; dashed lines, 95\% confidence interval, removed for clarity in b).

logical changes identified on samples taken from the failed patients in our series were similar. Persistent undiagnosed pain may be caused by excessive inflammatory fluid around the hip, possibly resulting from a reaction to metal wear debris. $^{52,53}$

The Australian Joint Registry reported in 2007 that the ASR and the Durom resurfacing device (Zimmer, Warsaw, Indiana) had twice the revision rate of other resurfacing implants. ${ }^{29}$ Siebel et $\mathrm{al}^{20}$ defined a learning curve in implanting the first 300 ASRs with a revision rate of $5 \%$ in the first 100 and of $1 \%$ in the final 100 . However, we found that not all failures related to metal wear debris occurred before two years. Worryingly, we therefore expect the rate of failure to increase with time.
The latest generation of resurfacing devices, such as the ASR, have a number of perceived advantages of design over previous generations, such as a subhemispherical acetabular component and lower clearance between components. However, low clearance may actually increase metal wear and the subhemispherical design could increase the risk of edge loading of the acetabular component, especially in malpositioned, small components. ${ }^{54}$ All fractures related to metal wear debris had a high inclination $\left(49^{\circ}\right.$ to $\left.61^{\circ}\right)$ and anteversion angle $\left(19^{\circ}\right.$ to $\left.30^{\circ}\right)$ for the acetabular component compared with the mean values for the group as a whole $\left(49^{\circ}\right.$ and $20^{\circ}$, respectively). These findings were similar to those of Hart et $\mathrm{al}^{55}$ in a series of patients with painful hip resurfacing.

Narrowing of the femoral neck as a result of stress shielding has been associated with late fracture in earlier resurfacing designs. ${ }^{56}$ Narrowing has been identified in $90 \%$ of patients with the Cormet 2000 (Corin, Cirencester, United Kingdom) and in $77 \%$ of those with a BHR. ${ }^{27,28}$ Both studies suggested that thinning only occurred in the first three years. In the latter group $28 \%$ had thinning of more than $10 \%$, but there was no increase in the rate of fracture. ${ }^{27}$ However, historical data suggest that fractures can occur later than this. ${ }^{56}$ We observed thinning of the neck in $60 \%$ of our hips at a mean of 43 months, but found that no hip had thinning of more than $10 \%$. This may be a consequence of the design changes to the internal geometry of the femoral component, which allows more even distribution of stresses, and the use of a non-load bearing stem, unlike other systems.

In our series, radiological evidence of $\mathrm{HO}$ was seen in a similar proportion of hips $(44 \%)$ to that reported after implantation of the Durom prosthesis. ${ }^{57}$ However, unlike with the Durom, our patients had HO of only Brooker grades I and II.

An observational study from a single surgeon has obvious limitations. However, this in-depth analysis has allowed causes of failure to be explored, which is not always possible with joint registers. Our patients experienced a high rate of failure compared with that of specialist centres, and with those using other designs of implant but our findings for the ASR mirrored those described in the Australian $^{29}$ and England and Wales registries. ${ }^{3}$ Failure of the implant was multifactorial, and extensive analysis of the in vivo experience is crucial to establish firm associations. Strict selection criteria are crucial for reducing complications. It could be argued that changes to our criteria could improve the outcome. However, there are encouraging results in the literature for the use of hip resurfacing in end-stage $\mathrm{AVN}^{58,59}$ and in men over 60 years of age. ${ }^{60,61} \mathrm{At}$ our centre we therefore continue to offer this procedure to patients in these groups, albeit cautiously. In addition, we have identified factors, such as the small size of the femoral component and the suboptimal positioning of the acetabular component, which elevate whole blood levels of metal ions ${ }^{37}$ and reduce functional outcome scores. ${ }^{62}$ We have been able 
to modify our selection criteria and surgical technique, based on these studies, with the hope of improving the survival of the implant.

The National Institute for Clinical Excellence ${ }^{63}$ in the United Kingdom considers a resurfacing device appropriate for young, active patients under 65 years of age who would otherwise receive a conventional THR, but who are likely to outlive all currently available THR implants. It states that surgeons should choose a device for which there are data available for at least three years. Assumptions on the longevity of the implant of new prostheses should not be based on other similar resurfacing designs. Our data describe an unacceptably high rate of failure for small ASR components, and we have therefore ceased to use it in patients requiring an acetabular component smaller than $56 \mathrm{~mm}$. This represents around $90 \%$ of our female patients in this group. After modifications to our selection criteria and surgical technique, we are continuing to use the larger components in the context of a prospective, independent study, given the encourging results in this group and the low levels of metal ions. ${ }^{37}$

The authors wish to acknowledge the contribution of Dr Raju for helping to classify Ficat stage of avascular necrosis of the femoral head.

One or more of the authors has received or will receive benefits for personal or professional use from a commercial party related directly or indirectly to the subject of this article. In addition, benefits have been made or will be directed to a research fund, foundation, educational institute, or other non-profit organisation with which one or more of the authors are associated.

\section{References}

1. Malchau H, Herberts P, Eisler T, Garellick G, Soderman P. The Swedish total hip replacement register. J Bone Joint Surg [Am] 2002;84-A(Suppl):2-20.

2. Puolakka TJ, Pajamäki J, Halonen PJ, et al. The Finnish Arthroplasty Register: report of the register. Acta Orthop Scand 2001;72:433-41.

3. No authors listed. National Joint Registry. National Joint Registry for England and Wales 5th Annual clinical report. www.njrcentre.org.uk (date last accessed 24 April 2009).

4. Grigoris $\mathbf{P}$, Roberts $\mathbf{P}$, Panousis $\mathbf{K}$, Bosch H. The evolution of hip resurfacing arthroplasty. Orthop Clin North Am 2005;36:125-34.

5. Amstutz HC, Grigoris P, Dorey FJ. Evolution and future of surface replacement of the hip. J Orthop Sci 1998;3:169-86.

6. Shimmin AJ, Bare J, Back DL. Complications associated with hip resurfacing arthroplasty. Orthop Clin North Am 2005;36:187-93.

7. Ball ST, Le Duff MJ, Amstutz HC. Early results of conversion of a failed femoral component in hip resurfacing arthroplasty. J Bone Joint Surg [Am] 2007;89-A:735-41.

8. McGrath MS, Marker DR, Seyler TM, Ulrich SD, Mont MA. Surface replacement is comparable to primary total hip arthroplasty. Clin Orthop 2009;467:94-100.

9. Girard J, Lavigne M, Vendittoli PA, Roy AG. Biomechanical reconstruction of the hip: a randomised study comparing total hip resurfacing and total hip arthroplasty. $J$ Bone Joint Surg [Br] 2006;88-B:721-6.

10. Pollard TCB, Baker RP, Eastaugh-Waring SJ, Bannister GC. Treatment of the young active patient with osteoarthritis of the hip: a five- to seven-year comparison of hybrid total hip arthroplasty and metal-on-metal resurfacing. J Bone Joint Surg [Br] 2006;88-B:592-600.

11. Mont MA, Marker DR, Smith JM, Ulrich SD, McGrath MS. Resurfacing is comparable to total hip arthroplasty at short-term follow-up. Clin Orthop 2009;467:66-71.

12. Vail TP, Mina CA, Yergler JD, Pietrobon R. Metal-on-metal hip resurfacing compares favourably with THA at 2 years follow-up. Clin Orthop 2006;453:123-31.

13. Daniel J, Pynsent PB, McMinn DJW. Metal-on-metal resurfacing of the hip in patients under the age of 55 years with osteoarthritis. J Bone Joint Surg [Br] 2004;86B:177-84

14. Treacy RBC, McBryde CW, Pynsent PB. Birmingham hip resurfacing arthroplasty: a minimum follow-up of five years. J Bone Joint Surg [Br] 2005;87-B:167-70.
15. Amstutz HC, Le Duff MJ. Eleven years of experience with metal-on-metal hybrid hip resurfacing: a review of 1000 conserve plus. J Arthroplasty 2008;23(Suppl 1):36-43.

16. Heilpern GN, Shah NN, Fordyce MJ. Birmingham hip resurfacing arthroplasty: a series of 110 consecutive hips with a minimum five-year clinical and radiological follow-up. J Bone Joint Surg [Br] 2008;90-B:1137-42.

17. Steffen RT, Pandit HP, Palan J, et al. The five-year results of the Birmingham Hip Resurfacing arthroplasty: an independent series. J Bone Joint Surg [Br] 2008;90B:436-41.

18. Khan M, Kuiper JH, Edwards D, Robinson E, Richardson JB. Birmingham hip arthroplasty five to eight years of prospective multicenter results. J Arthroplasty 2008; Epub.

19. Shimmin AJ, Back DL. Femoral neck fractures following Birmingham hip resurfacing: a national review of 50 cases. J Bone Joint Surg [Br] 2005;87-B:463-4.

20. Siebel T, Maubach S, Morlock MM. Lessons learned from early clinical experience and results of 300 ASR hip resurfacing implants. Proc Inst Mech Eng [H] 2006;220:345-53

21. Willert HG, Buchhorn GH, Fayyazi A, et al. Metal-on-metal bearings and hypersensitivity in patients with artificial hip joints: a clinical and histomorphological study. J Bone Joint Surg [Am] 2005;87-A:28-36.

22. Pandit H, Glyn-Jones S, McLardy-Smith P, et al. Pseudotumours associated with metal-on-metal hip resurfacings. J Bone Joint Surg [Br] 2008;90-B:847-51.

23. Campbell P, Shimmin A, Walter L, Solomon M. Metal sensitivity as a cause of groin pain in metal-on-metal hip resurfacing. J Arthroplasty 2008;23:1080-5.

24. Isaac GH, Siebel T, Schmalzried TP, et al. Development rationale for an articular surface replacement: a science-based evolution. Proc Inst Mech Eng [H] 2006;220:253-68.

25. Grigoris $\mathbf{P}$, Roberts $\mathbf{P}$, Panousis $\mathbf{K}$, Jin Z. Hip resurfacing arthroplasty: the evolution of contemporary designs. Proc Inst Mech Eng [H]2006;220:95-105.

26. Dowson D, Hardaker C, Flett M, Isaac GH. A hip simulator study of the performance of metal-on-metal joints. Part II: design. J Arthroplasty 2004;19(Suppl 3):12430

27. Hing CB, Young DA, Dalziel RE, et al. Narrowing of the neck in resurfacing arthroplasty of the hip: a radiological study. J Bone Joint Surg [Br] 2007;89-B:1019-24.

28. Spencer S, Carter R, Murray H, Meek RM. Femoral neck narrowing after metalon-metal hip resurfacing. J Arthroplasty 2008;23:1105-9.

29. No authors listed. Australian Orthopaedic Association. National Joint Replacement Registry. Annual Report 2008. http://www.dmac.adelaide.edu.au/aoanjrr/index.jsp (date last accessed 25 April 2009).

30. The American Society of Anaesthesiologists. New classification of physical status. Anesthesiology 1963;24:111.

31. Charnley J. The long-term results of low friction arthroplasty of the hip performed as a primary intervention. J Bone Joint Surg [Br] 1972;54-B:61-76.

32. Ficat RP. Idiopathic bone necrosis of the femoral head: early diagnosis and treatment. J Bone Joint Surg [Br] 1985;67-B:3-9.

33. Anglin C, Masri BA, Tonetti J, Hodgson AJ, Greidanus NV. Hip resurfacing femoral neck fracture influenced by valgus placement. Clin Orthop 2007;465:71-9.

34. Harris WH. Traumatic arthritis of the hip after dislocation and acetabular fractures: treatment by mold arthroplasty: an end-result study using a new method of result evaluation. J Bone Joint Surg [Am] 1969:51-A:737-55.

35. Amstutz HC, Thomas BJ, Jinnah R, et al. Treatment of primary osteoarthritis of the hip: a comparison of total joint and surface replacement arthroplasty. J Bone Joint Surg [Am] 1984;66-A:228-41.

36. Murray DW. The definition and measurement of acetabular orientation. J Bone Joint Surg [Br] 1993;75-B:228-32.

37. Langton DJ, Jameson SS, Joyce TJ, Webb J, Nargol AVF. The effect of component size and orientation on concentrations of metal ions after resurfacing arthroplasty of the hip. J Bone Joint Surg [Br] 2008;90-B:1143-51

38. DeLee JG, Charnley J. Radiological demarcation of cemented sockets in total hip replacement. Clin Orthop 1976;121:20-32.

39. Beaulé PE, Dorey FJ, LeDuff M, Gruen T, Amstutz HC. Risk factors affecting outcome of metal-on-metal surface arthroplasty of the hip. Clin Orthop 2004;418:87-93.

40. Amstutz HC, Beaulé PE, Dorey FJ, et al. Metal-on-metal hybrid surface arthroplasty: two to six-year follow-up study. J Bone Joint Surg [Am] 2004;86-A:28-39.

41. Brooker AF, Bowerman JW, Robinson RA, Riley LH. Ectopic ossification following total hip replacement: incidence and a method of classification. J Bone Joint Surg [Am] 1973;55-A:1629-32.

42. Langton DJ, Jameson SS, Joyce TJ, Natu S, Nargol AVF. Early failure of metalon-metal bearings in hip resurfacing and large-diameter total hip replacement. J Bone Joint Surg [Br] 2010; 92-B:38-46.

43. Ng CY, Ballantyne JA, Brenkel IJ. Quality of life and functional outcome after primary total hip replacement: a five-year follow-up. J Bone Joint Surg [Br] 2007;89B:868-73. 
44. Jacobs JJ, Hallab NJ. Loosening and osteolysis associated with metal-on-meta bearings: a local effect of metal hypersensitivity? J Bone Joint Surg [Am] 2006;88A:1171-2.

45. MacDonald SJ. Metal-on-metal total hip arthroplasty: the concerns. Clin Orthop 2004;429:86-93.

46. Hart AJ, Hester T, Sinclair K, et al. The association between metal ions from hip resurfacing and reduced T-cell counts. J Bone Joint Surg [Br] 2006;88-B:449-54.

47. Daniel J, Ziaee H, Pradham C, Pynsent PB, McMinn DJ. Blood and urine meta ion levels in young and active patients after Birmingham hip resurfacing arthroplasty: four year results of a prospective longitudinal study. J Bone Joint Surg [Br] 2007;89B:169-73.

48. Keegan GM, Learmonth ID, Case CP. Orthopaedic metals and their potential tox icity in the arthroplasty patient: a review of current knowledge and future strategies. J Bone Joint Surg [Br] 2007;89-B:567-73.

49. Elves MW, Wilson JN, Scales JT, Kemp HBS. Incidence of metal sensitivity in patients with total joint replacements. Br Med J 1975;4:376-8.

50. Sweetnam R. Metal sensitivity. J Bone Joint Surg [Br] 1974;56-B:601-2.

51. Davies AP, Willert HG, Campbell PA, Learmonth ID, Case CP. An unusual lymphocytic perivascular infiltration in tissues around contemporary metal-on-metal joint replacements. J Bone Joint Surg [Am]2005;87-A:18-27.

52. Hallab N, Merritt K, Jacobs JJ. Metal sensitivity in patients with orthopaedic implants. J Bone Joint Surg [Am] 2001;83-A:428-36

53. Evans EM, Reeman MAR, Miller AJ, Vernon-Roberts B. Metal sensitivity as cause of bone necrosis and loosening of the prosthesis in total joint replacement. $J$ Bone Joint Surg [Br] 1974;56-B:626-42.
54. Langton DJ, Sprowson AP, Jameson SS, et al. Metal ion levels post-hip resurfacing: ASR and BHR. J Bone Joint Surg [Br] 2010;92-B(Suppl); in press.

55. Hart AJ, Sabah S, Henckel J, et al. The painful metal-on-metal hip resurfacing. J Bone Joint Surg [Br] 2009;91-B:738-44.

56. Ritter MA, Lutgring JD, Berend MD, Pierson JL. Failure mechanisms of total hip resurfacing: implications for the present. Clin Orthop 2006;453:110-14.

57. Rama KR, Vendittoli PA, Ganapathi M, et al. Heterotopic ossification after surface replacement arthroplasty and total hip arthroplasty: a randomized study. $J$ Arthroplasty 2008;24:256-62.

58. Revell MP, McBryde CW, Bhatnagar S, Pynsent PB, Treacy RB. Metal-on-metal hip resurfacing in osteonecrosis of the femoral head. J Bone Joint Surg [Am]2006;88A(Suppl 3):98-103.

59. Beaulé PE, Amstutz HC. Management of Ficat stage III and IV osteonecrosis of the hip. J Am Acad Orthop Surg 2004;12:96-105.

60. McGrath MS, Desser DR, Ulrich SD, et al. Total hip resurfacing in patients who are sixty years of age or older. J Bone Joint Surg [Am] 2008;90-A(Suppl 3):27-31.

61. Jameson SS, Langton DJ, Natu S, Nargol TV. The influence of age and sex on early clinical results after hip resurfacing: an independent center analysis. J Arthroplasty 2008;23(Suppl 1):50-5

62. Langton DJ, Jameson SS, Ramisetty N, Webb J, Nargol AVF. The effect of femoral component size on functional outcome and metal ion levels following hip resurfacing. J Bone Joint Surg [Br] 2010;92-B(Suppl); in press.

63. No authors listed. National Institute for Clinical Excellence (NICE). 2002/034 NICE recommends the selective use of metal on metal hip resurfacing. http:// www.nice.org.uk/page.aspx?0=33568 (date last accessed 25 April 2009). 